\title{
Hubungan kadar hemoglobin dengan peluang remisi pada anak penderita leukemia limfoblastik akut periode 2010-2014 di RSUP Prof. Dr. R. D. Kandou Manado
}

\author{
${ }^{1}$ Sharon Tewuh \\ ${ }^{2}$ Max F. J. Mantik \\ ${ }^{2}$ Sarah M. Warouw
}

\author{
${ }^{1}$ Kandidat Skripsi Fakultas Kedokteran Universitas Sam Ratulangi Manado \\ ${ }^{2}$ Bagian Ilmu Kesehatan Anak Fakultas Kedokteran Universitas Sam Ratulangi Manado \\ Email: sharon_12255@yahoo.com
}

\begin{abstract}
Acute lymphocytic leukemia (ALL), also called acute lymphoblastic leukemia, is a cancer that starts from the initial stem cells of the lymphocytes in the bone marrow. This study aimed to determine the relationship of hemoglobin level with the chance of remission in children with ALL. This was an analytical retrospective study. Data were obtained from the medical records of Estella at Prof. Dr. R. D. Hospital period 2010-2014 with a total samples of 30 patients. The Fisher exact test showed a significant $p$ value of $0.019(p<0.05)$. Conclusion: There was a significant relationship between hemoglobin level and the chance of remission in patients with ALL.
\end{abstract}

Keywords: hemoglobin level, remission, acute lymphoblastic leukemia

\begin{abstract}
Abstrak: Leukemia limfositik akut (LLA), juga disebut leukemia limfoblastik akut, adalah kanker yang dimulai dari sel stem awal dari limfosit dalam sumsum tulang. Penelitian ini bertujuan untuk mengetahui hubungan kadar $\mathrm{Hb}$ dengan peluang remisi pada anak penderita LLA. Jenis penelitian ini ialah analitik retrospektif dengan menggunakan data rekam medik di ruang Estella RSUP Prof. Dr. R. D. Kandou periode 2010-2014 dengan sampel sebanyak 30 pasien. Hasil uji Fisher exact test menunjukkan nilai signifikasi $p=0,019(p<0,05)$. Simpulan: Terdapat hubungan bermakna antara kadar $\mathrm{Hb}$ dengan peluang remisi pada pasien LLA.
\end{abstract}

Kata kunci: kadar $\mathrm{Hb}$, remisi, LLA

Angka kejadian leukemia limfositik akut (LLA) di Amerika serikat dan Eropa pada anak di bawah usia 15 tahun, per tahun sekitar 3,5-4,0 per 100.000 anak. Rasio laki-laki dan perempuan yang menderita LLA sebesar 1,2 dan angka tertinggi pada anak usia 2-7 tahun yang jumlahnya dapat mencapai 10 per 100.000 anak. $^{1}$

Pasien dimasukkan kategori risiko tinggi (HR) bila jumlah leukosit darah tepi $>50.000 / \mathrm{ml}$, ditemukan sel blas pada susunan saraf pusat, jumlah total blast setelah 1 minggu diterapi lebih dari $1000 / \mathrm{mm}^{3}$, ada massa di mediastinum, dan umur $<1$ tahun atau $>10$ tahun. Anemia didefinisikan sebagai penurunan kadar hemoglobin darah di bawah nilai normal untuk anak, usia, dan jenis kelamin. Gambaran klinis pada LLA biasanya terjadi kegagalan sumsum tulang berupa anemia dengan kadar $\mathrm{Hb}$ antara 5 sampai $<10$ g/dL, neutropenia berupa demam dan trombositopenia. ${ }^{1-3}$

Pada penderita LLA, dinyatakan remisi komplit bila tidak ada keluhan dan bebas gejala klinis leukemia; pada aspirasi sumsum tulang didapatkan jumlah sel blas $<$ $5 \%$ dari sel berinti; hemoglobin $>12 \mathrm{~g} / \mathrm{dl}$ tanpa transfuse; jumlah leukosit $>3000 / \mu \mathrm{l}$ dengan hitung jenis leukosit normal, 
jumlah granulosit $>2000 / \mu \mathrm{l}$, dan jumlah trombosit $>100.000 / \mu l$; dan pemeriksaan cairan serebrospinal normal. Dengan pemberian terapi, remisi akan tercapai pada 98\%. Sekitar 2-3\% dari pasien anak akan meninggal dalam continuous complete remission (CCR) dan 25-30\% akan kambuh. $^{4}$

\section{METODE PENELITIAN}

Jenis penelitian ini ialah analitik retrospektif dengan desain potong lintang. Pengumpulan data kadar hemoglobin pasien yang sudah dan belum mengalami remisi pada LLA di Ruang Estella RSUP Prof. Dr. R. D. Kandou Manado periode 2010-2014. Data dievaluasi dan dianalisis untuk melihat peluang remisi dari pasien.

Populasi penelitian ialah seluruh pasien di Ruang Estella RSUP Prof. Dr. R. D. Kandou Manado. Sampel penelitian ialah pasien LLA yang dirawat periode 2010-2014. Analisis data diolah menggunakan SPSS untuk mengetahui korelasi variabel penelitian. Uji statistik dengan Fisher exact test. Hubungan dinyatakan bermakna jika didapatkan p < 0,05 . Semua analisis dilakukan dengan software SPSS 20.0.

\section{HASIL PENELITIAN}

Penelitian ini dilakukan pada pasien LLA dengan mengambil data rekam medik di Ruang Estella Bagian Ilmu Kesehatan Anak. Jumlah sampel penelitian sebanyak 30 pasien anak.

Tabel 1 menunjukkan data karakteristik demografi, dimana usia dengan nilai terendah 4 tahun dan tertinggi 16 tahun sedangkan rata-rata keseluruhan sampel 9,10 dan simpangan baku untuk usia 3,305. Kadar $\mathrm{Hb}$ dengan nilai terendah 6,4 dan tertinggi 12,5 sedangkan rata-rata keseluruhan sampel ialah 9,67 dan simpangan baku 1,951.

Pada Gambar 1 dapat dilihat distribusi sampel menurut jenis kelamin Dari 30 sampel jumlah laki-laki sebanyak 16 orang (53\%) dan perempuan 14 orang (47\%).

Tabel 2 menunjukkan distribusi risiko LLA berdasarkan jenis kelamin. Dari 30 sampel jumlah laki-laki risiko standar (SR) 9 (30,0\%) dan risiko tinggi (HR) 7 (23,3\%) dengan total $16(53,3 \%)$ sedangkan pada perempuan risiko standar 7 (23,3\%) dan risiko tinggi 7 (23,3\%) dengan total 14 (46,7\%).

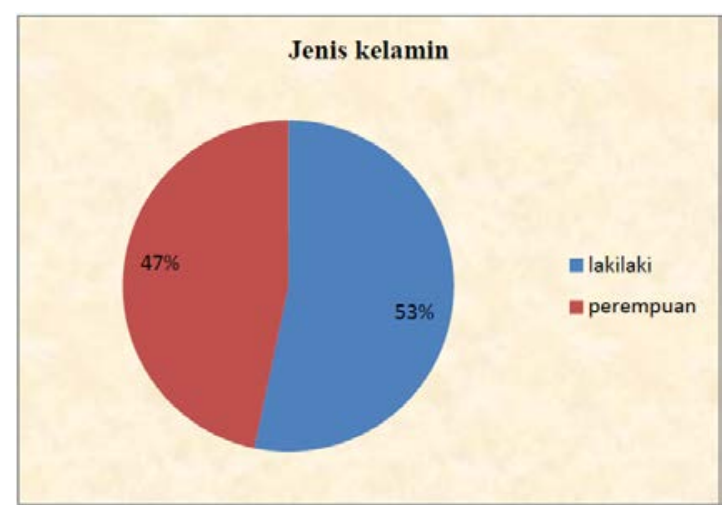

Gambar 1. Bagan distribusi sampel menurut jenis kelamin

Tabel 3 memperlihatkan analisis hubungan kadar $\mathrm{Hb}$ dengan remisi pada LLA. Dari 30 sampel pasien yang memiliki kadar $\mathrm{Hb}<11 \mathrm{~g} / \mathrm{dL}$, yang sudah remisi 5 (16,7\%) dan yang belum 20 (66,7\%) sedangkan pada pasien yang memilki kadar $\mathrm{Hb}>11 \mathrm{~g} / \mathrm{dL}$ yang sudah remisi 4 (13,3\%) dan yang belum remisi 1 (3,3\%). Hasil analisis Fisher exact test mendapatkan nilai $p=0,019 \quad(p<0,05)$ yang berarti terdapat hubungan bermakna antara kadar $\mathrm{Hb}$ dengan remisi.

Tabel 1. Data karakteristik demografi ( Umur, Kadar Hb)

\begin{tabular}{cccccc}
\hline Variabel & $\mathbf{N}$ & $\begin{array}{c}\text { Nilai } \\
\text { terendah }\end{array}$ & $\begin{array}{c}\text { Nilai } \\
\text { tertinggi }\end{array}$ & Rerata & $\begin{array}{c}\text { Simpangan } \\
\text { baku }\end{array}$ \\
\hline Usia & 30 & 4 & 16 & 9,10 & 3,305 \\
Kadar hemoglobin & 30 & 6.4 & 12.5 & 9,67 & 1,951 \\
\hline
\end{tabular}


Tabel 2. Distribusi risiko LLA berdasarkan jenis kelamin

\begin{tabular}{lccccc}
\hline Jenis & \multicolumn{4}{c}{ Risiko } & Total \\
\cline { 2 - 5 } Kelamin & SR & $\%$ & HR & $\%$ & (\%) \\
\hline Laki-laki & 9 & $30,0 \%$ & 7 & $23,3 \%$ & $53,3 \%$ \\
Perempuan & 7 & $23,3 \%$ & 7 & $23,3 \%$ & $46,7 \%$ \\
Total & & & & & $100 \%$ \\
\hline
\end{tabular}

Tabel 3. Analisis hubungan kadar Hb dengan remisi pada LLA

\begin{tabular}{cccc}
\hline \multirow{2}{*}{ Kadar Hemoglobin } & \multicolumn{2}{c}{ Remisi } & \multirow{2}{*}{ P } \\
\cline { 2 - 3 } & Sudah & Belum & \\
\hline Rendah $(<11 \mathrm{~g} / \mathrm{dL})$ & $5(16,7 \%)$ & $20(66,7 \%)$ & 0,019 \\
Tinggi $(>11 \mathrm{~g} / \mathrm{dL})$ & $4(13,3 \%)$ & $1(3,3 \%)$ & \\
\hline
\end{tabular}

\section{BAHASAN}

Pada analisis data rekam medik bias dilihat terdapat hubungan bermakna antara kadar $\mathrm{Hb}$ dengan peluang remisi berdasarkan uji korelasi menggunakan uji Fisher exact test (Tabel 3). Pada penelitian Muliyani et al. ${ }^{5}$ didapatkan dari 25 sampel jumlah laki-laki sebesar $76 \%$ dan perempuan sebesar 24\% dengan jumlah laki-laki yang terbanyak; hal ini hampir serupa dengan penelitian ini yaitu laki-laki yang terbanyak dengan jumlah 53\% sedangkan perempuan $47 \%$. Hal ini sesuai dengan teori yang menyebutkan bahwa anak laki-laki lebih sering dari pada anak perempuan. $^{5,6}$

Klasifikasi risiko standar atau resiko tinggi menetukan protokol kemoterapi. Berdasarkan protokol WK-ALL dan protokol nasional pasien LLA dimasukkan dalam kategori risiko tinggi bila jumlah leukosit $>50.000 / \mu l$. Pada penelitian Yetty dari jumlah sampel 119 didapatkan jumlah laki-laki dengan risiko standar 39 dan risiko tinggi 36, sedangkan pada perempuan dengan risiko standar 31 dan risiko tinggi 13. Dari kedua protokol tersebut dapat dilihat laki-laki yang lebih banyak sedangkan pada penelitian ini (dilihat pada tabel 4) dari jumlah sampel 30 didapatkan risiko standar untuk laki-laki 9 dan risiko tinggi 7 , sedangkan risiko standar untuk perempuan 7 dan risiko tinggi. Dapat dilihat bahwa hanya pada risiko standar terdapat kesamaan laki-laki lebih tinggi sedangkan pada perempuan memilki jumlah yang sama yang mungkin disebabkan karena kurangnya jumlah sampel pada penelitian ini. ${ }^{4,7}$

Pasien dinyatakan remisi komplit bila tidak ada keluhan dan bebas gejala klinis leukemia; pada aspirasi sumsum tulang didapatkan jumlah sel blas $<5 \%$ dari sel berinti; hemoglobin $>12 \mathrm{~g} / \mathrm{dl}$ tanpa transfusi; jumlah leukosit $>3000 / \mu$ l dengan hitung jenis leukosit normal; jumlah granulosit >2000/ $\mu$; jumlah trombosit $>100.000 / \mu \mathrm{l}$; dan pemeriksaan cairan serebrospinal normal. Tabel 3 memperlihatkan hubungan kadar $\mathrm{Hb}$ dengan peluang remisi pada pasien LLA. Dari 30 sampel dengan $\mathrm{Hb}<11$ g/dl yang sudah mengalami remisi $16,7 \%$ sedangkan yang belum remisi 66,7\%, sedangkan untuk kadar $\mathrm{Hb}>11 \mathrm{~g} / \mathrm{dl}$ didapatkan pasien yang sudah remisi 13,3\% dan yang belum remisi 3,3\%. Hasil uji korelasi dengan Fisher exact test mendapatkan nilai $\mathrm{p}=0,019$ yang menunjukkan bahwa kadar Hb memiliki hubungan bermakna dengan peluang remisi pada pasien LLA. ${ }^{4}$

\section{SIMPULAN}

Dari hasil penelitian pada pasien leukemia limfoblastik akut dapat disimpulkan bahwa terdapat hubungan bermakna antara kadar hemoglobin dengan peluang remisi. 
DAFTAR PUSTAKA

1. Hoffbrand AV, Moss PAH. Kapita Selekta Hematologi (6th rev. ed). In: Brahm U, Setiawan L, Iriani A, translators. Jakarta: EGC, 2014; p. 13-21.

2. Isnani N, Perwitasari D.A, Andalusia R, Mahdi HI. Evaluasi toksisitas hematologi akibat penggunaan 6merkaptopurin dalam fase pemeliharaan pada pasien penderita kanker leukemia limfoblastik akut di RS Kanker Dharmais Jakarta. Media Farmasi. 2014;11(1):90-97.

3. Bertrand D. Acute lymphoblastic leukemia. Amgen: 2014:6-52.

4. Bambang HP, Sutaryo, Ugrasena IDG, EndangW, Maria A. Buku Ajar Hematologi-Onkologi anak. (3th rev. ed). Jakarta: Ikatan Dokter Anak Indonesia, 2010; p. 241-3.

5. Muliyani, Dyah AP, Rizka A, Mururul A. Evaluasi penggunaan antibiotik pada pasien pediatric leukemia limfoblastik akut dengan febrile neutropenia selama pemberian kemoterapi di rumah sakit kanker Dharmais Jakarta. Media Farmasi. 2014;11(1):101-2.

6. Nugroho S. Gangguan keseimbangan elektrolit sesudah kemoterapi induksi remisi pada dengan Leukimia Limfoblastik akut. Jurnal Kedokteran Brawijaya. 2010;26(1):1-5.

7. Yetty MN. Perbedeaan kebutuhan transfusi darah selama fase induksi pada leukemia limfoblastik akut. Sari Pediatri. 2011;13(4):272. 